\title{
Prof. Charles Flahault and the Scots College at Montpellier
}

\section{Proposed Memorial}

$\mathrm{M}$ EN of science throughout the world will welcome the news that a movement is afoot to commemorate the work of the great geobotanist Charles Flahault. A committee of patronage has been founded to erect in L'Hort de Dieu, on Mont Aigoual, a commanding peak of 5,000 ft. in the Cevennes, a monument to the memory of this noted savant and essentially human figure. Flahault began life in modest circumstances. From being gardener of the Natural History Museum, Paris, he attained, through his undoubted ability, his application and hard work, the highest university degrees. At twenty-six years of age he found his place among the young savants of great promise. As professor in the Faculté des Sciences in 1883, he worked and taught for forty-four years in Montpellier, the University of which he never abandoned in spite of repeated calls of the Natural History Museum and of the Sorbonne.

Flahault was the founder in France of botanical geography, the aims, the methods and nomenclature of which he clearly defined. He organised the Botanical Institute of Montpellier, and by his learned words and guiding influence made Montpellier a noted centre for Mediterranean studies. His scientific activity aimed through all his life's work at an essentially human goal. He sought to discover and to teach the relationship of plant life to its environment and thereby to increase the yield of Nature for the benefit of man.

In retirement, Flahault turned his attention to the replanting of the garrigues and mountains, to the improvement of the cultural aspect of sand-dunes and to the uncultivated marshes which border the lagoons. The last seven years of his life were spent in this work, unceasingly giving practical advice, writing reports, articles and booklets into which he condensed the results of his researches and experiments. These included observations which he had made on the Aigoual in the Hort de Dieu, where he founded a botanical mountain garden and laboratory. Thus from the lagoons of the seashore to his hillstation on the edge of the Massif Central, Flahault revealed the unity of Mediterranean vegetation.

To students and men of science from Great Britain, the special significance of Montpellier and its region is its key-position at that point of the Mediterranean lands which is nearest to our own. This fact formed a fertile contact between Flahault and ecologists from our own shores. The unbroken friendship of the late Sir Patrick Geddes and Flahault, dating from the 'eighties, led to the founding of the Scots College (Le Collège des Ecossais) at Montpellier, and Geddes taking up residence there in 1924; the garden of the College with its wide variety of garrigue flora was planned by the two friends as an ecological museum of Mediterranean vegetation. Latterly, a co-worker of Flahault, M. Braun-Blanquet, has placed his Station Internationale geo-Botanique Mediterranéenne et Alpine (S.I.G.M.A.) in the College garden. Recently, at the College itself, the warden, M. Paul Reclus, has aided the supervision of ecological studies by British students. Thus the work of Flahault is continued, not only by his successor M. Pavillard at the University, but also at the College where so much of his time was spent. Students are ever welcome to this centre of study and research, and it is hoped that the College with such a beginning and tradition will receive the support of those interested in the allied sciences.

\section{Progress in Road Research}

HE first report of the Road Research Board,
covering the two years ended on March 31,
1935, since the Department of Scientific and Indus-
trial Research assumed responsibility for the
researches on roads carried out at the Road Re-
search Laboratory, Harmondsworth (H.M. Stationery
Office. 3s. net), appears appropriately enough when
an important discussion on science and the control
of road traffic at the British Association meetings at
Norwich has directed attention to the importance of
road surface and similar factors in the prevention of
accidents. A major group of problems with which the
work of the Board is concerned is directly related to
the reduction of accident ratios, the other main group
of problems being concerned with economy in road
construction and maintenance.
The report of the Board itself outlines the general
policy pursued in its work and is followed by the
report of the Director of Road Research. The first
section of the latter report outlines a preliminary programme of research covering both materials and processes for road-making and providing for routine tests and ad hoc investigations by the highway authorities and the Ministry of Transport, which under the present scheme remains responsible for fullscale tests outside the Laboratory and is the channel of communication with highway authorities. This programme is designed to supply a real knowledge of all the fundamental factors involved in the pro. cesses and materials used by the industry, and the work falls into four main divisions : road construction, road usage, development of special testing apparatus, physiological and psychological effects.

The major part of the report is concerned with materials and processes for road construction. Investigations are outlined dealing with questions of the settlement, drainage and other characteristics of the sub-soil which are of importance with the use of large impervious surfaces in modern roads. The properties of the various road materials and their 